\title{
Improvement of the Antioxidant Activity of Soybean Peptides by Microwave-Assisted Enzymatic Digestion
}

\author{
Ting Zhang \\ Laboratory of Nutrition and Functional Food \\ Jilin University \\ Changchun, P.R. China \\ tingzhang413@hotmail.com
}

Dan Liu

Laboratory of Nutrition and Functional Food

Jilin University

Changchun, P.R. China

841113767@qq.com

Jiyun Liu

Laboratory of Nutrition and Functional Food

Jilin University

Changchun, P.R. China

hanches1124@gmail.com

\author{
Yuquan Zhou \\ Laboratory of Nutrition and Functional Food \\ Jilin University \\ Changchun, P.R. China \\ 914979088@qq.com \\ Shuang Ma \\ Laboratory of Nutrition and Functional Food \\ Jilin University \\ Changchun, P.R. China \\ mashuang6867736@163.com \\ Jingbo Liu* \\ Laboratory of Nutrition and Functional Food \\ Jilin University \\ Changchun, P.R. China \\ ljb168@sohu.com
}

\begin{abstract}
Objective: To optimize the enzymatic digestion processing parameters of soybean and improve the antioxidant activity of soybean peptides. Methods: microwave-assisted enzymatic digestion (MAED) was applied to extract antioxidant peptides from soybean with maximized antioxidant activity by response surface methodology coupled with an one-factor-at-a-time design. The hydroxyl radical, DPPH radical, superoxide anion radical and ABTS radical scavenging activity were used to evaluate the antioxidant power of the products. Results: The optimal processing parameters for MAED were $31 \mathrm{~min}$ for microwave time, $56{ }^{\circ} \mathrm{C}$ for microwave temperature, $500 \mathrm{~W}$ for microwave power, 8.09 for $\mathrm{pH}$ value, 5:100 for ratio of enzyme to soybean protein powder and $50 \mathrm{mg} / \mathrm{mL}$ for concentration of soybean protein powder. Under these conditions, soybean peptides demonstrated stronger antioxidant activities than soybean peptides without MAED $(\mathrm{P}<0.05)$. The $\mathrm{IC}_{50}$ value of DPPH radical, superoxide anion radical and ABTS radical scavenging of the final soybean peptides are $0.652 \pm 0.007 \mathrm{mg} / \mathrm{mL}, 1.250 \pm 0.046 \mathrm{mg} / \mathrm{mL}$ and $0.674 \pm 0.008 \mathrm{mg} / \mathrm{mL}$, respectively. Conclusion: The results suggested that the MAED technology has potentials to improve the antioxidant activity. Much more work should be done in the future to clarify the relation between the improved antioxidant activity and the changed functional groups.
\end{abstract}

Keywords-Soybean; peptides; Microwave-assisted enzymatic digestion; Response surface methodology; Antioxidant activity

\section{INTRODUCTION}

Reactive oxygen species and other free radical are produced constantly by normal metabolism in cell. Oxidative stress will occur when free radical production exceeds the tissue antioxidant capacity $[1 ; 2]$. Reactive oxygen species are known to play a significant role in the development of diseases, such as cardiovascular diseases, coronary heart diseases, diabetes mellitus, cancers and neurological disorders [3;4]. Furthermore, free radicals lead to rancidity and shelf-life reduction in many foods. Therefore, there is a growing interest in finding antioxidants from nature source, which may pose less potential health hazards than the synthetic ones do[5]. Soybean protein is widely used as a nutritional and functional ingredient in food products. Hydrolyzed soybean protein by different proteases has been reported to get improvement in functional properties, including emulsification capacity, solubility, and anti-fatigue activity [6]. Some of the hydrolyzed soybean protein had also been recognized to take antioxidant activity [7]. It is shown by some researchers using a triacylglycerol emulsion model system that soybean peptides had greater oxidation inhibition ability compared with other food proteins, such 
as milk casein and egg albumen [8]. Chemical hydrolysis of proteins could achieved by adding acid or alkaline, however many limitations may occur by this method, such as poor functionality, reduced nutritional qualities, and restricted efficacy as flavor enhancers [9]. Thus, more efficient method is needed for protein hydrolysis. Enzymatic treatment is a particularly promising and attractive technique owing to the milder process conditions required, the relatively easy way to control reactions, and minimal formation of by-products [10]. Nevertheless, conventional enzymatic hydrolysis methods have some drawbacks, typically the involvement of several hours or overnight incubations. In comparison to conventional heating, microwaves generate heat within the material, which leads to faster heating rates and shorter processing time. The traditional process which requires several hours under conventional conditions can often be completed in a few minutes with very high yields and reaction selectivity when microwave is employed [11]. The microwaveassisted approach is widely used in the food industry field. Juan et al. [12] applied microwave-assisted approach to digest proteins in solution and in gel with Trypsin within $10 \mathrm{~min}$, including a protein that was tightly folded and extremely resistant to denaturation (bovine ubiquitin). Recently, Pramanik et al. [13] also reported the use of microwave technology for selectively and rapidly enzymatic digestion of several proteins in aqueous solutions. Zhang et al. [14] used microwave technology to digest peanut proteins with Alcalase within $25 \mathrm{~min}$. Although the ability of microwave irradiation to accelerate enzymatic digestion was well acknowledged, the antioxidant activity of microwave-assisted digestion products has not been investigated.

In this paper, we applied microwave-assisted enzymatic digestion (MAED) technology to obtain soybean antioxidant peptides (SAP), and one-factor-at-atime (OFAT) tests and response surface methodology (RSM) analysis based on a Box-Behnken design (BBD) to optimize the conditions of enzymatic digestion. The antioxidant activities of SAP, such as scavenging hydroxyl radical, DPPH radical, superoxide anion radical and ABTS radical, were evaluated.

\section{MATERIALS AND METHODS}

\section{A. Materials and Reagent}

Soybean protein powder (protein content of $70 \%$ ) was obtained from Ningbo SuoBao Co. (China). 1, 1diphenylhy-2-picrylhdrazyl (DPPH), 2, 2-azinobis (3ethyl-benzothiazo line-6-sulfonic acid) (ABTS), were purchased from Sigma Chemicals Co. (USA). Alcalase was purchased from Fanfuer International Chem Co. (China). Other chemicals were analytical grade.

\section{B. Preparation of Soybean Antioxidant Peptides by MEAD Method}

A microwave extraction apparatus was used to carry out the MAED. Briefly, soybean protein powder was dissolved in $200 \mathrm{~mL}$ distilled water of a microwave extraction bottle followed by heat treatment at $90{ }^{\circ} \mathrm{C}$ for 10 $\min$ in a water bath to denature the protein. Then, the $\mathrm{pH}$ value of the suspension mixture was adjusted to the required value by phosphate buffer $(0.05 \mathrm{M})$. Varying amounts of Alcalase enzyme were added to the suspension mixture according to the experimental optimization. Then the suspension mixture was transferred into the microwave extraction apparatus and the agitator of microwave extraction apparatus was initiated [14]. When the reaction was finished, the solution was heated to $100{ }^{\circ} \mathrm{C}$ to inactivate the enzyme and then centrifuged at $8000 \times \mathrm{g}$ for $10 \mathrm{~min}$ at $4{ }^{\circ} \mathrm{C}$. The supernatant liquor was freeze-dried. Table 1. Independent variables and their levels used for Box-

\begin{tabular}{|c|c|c|c|}
\hline \multirow{2}{*}{ Behnken rotatable design } \\
\hline \multirow{2}{*}{ Independent variable } & \multicolumn{3}{|c|}{ Level } \\
\cline { 2 - 4 } & -1 & 0 & 1 \\
\hline Microwave time $\left(X_{I}\right)$ & 25 & 30 & 35 \\
\hline Microwave temperature $\left(X_{2}\right)$ & 50 & 55 & 60 \\
\hline $\mathrm{pH}$ value $\left(X_{3}\right)$ & 7.5 & 8.0 & 8.5 \\
\hline
\end{tabular}

Then the obtained powder was collected in sealed bags, and stored in desiccators until use. The microwave power $(300,400,500,600,700,800 \mathrm{~W})$, microwave time $(5,10$, $15,20,25,30,35,40,45 \mathrm{~min})$, experiment temperature (45, $\left.50,55,60,65,70{ }^{\circ} \mathrm{C}\right), \mathrm{pH}$ value $(7,7.5,8.0,8.5,9.0)$, ratio of enzyme to soybean protein powder $(3: 100,4: 100,5: 100$, $6: 100,7: 100,8: 100)$, concentration of soybean protein powder $(20,35,50,65,80,95 \mathrm{mg} / \mathrm{mL})$ were chosen as the independent variables. Their levels used for Box-Behnken rotatable design were showed in table 1. The MAED$500 \mathrm{~W}$ sample and MAED-0W sample was obtained under the same condition except the microwave power.

\section{Determination of Hydroxyl Radical Scavenging Activity}

The hydroxyl radical $(\cdot \mathrm{OH})$ scavenging activity of SAP was determined by the method of Huang et al. [15] with a slight modification. Firstly, $2 \mathrm{~mL}$ soybean peptides solution, $2 \mathrm{~mL} \mathrm{FeSO}_{4}(9 \mathrm{mM}), 2 \mathrm{~mL}$ salicylic acid-ethanol $(9 \mathrm{mM})$, and $2 \mathrm{~mL} \mathrm{H}_{2} \mathrm{O}_{2}(8.8 \mathrm{mM})$ were added to the test tube sequentially. The solutions were mixed and allowed to react at $37{ }^{\circ} \mathrm{C}$ for $30 \mathrm{~min}$. Then the absorbance at 510 $\mathrm{nm}$ was read. All the measurements were carried out in triplicate. The scavenging activity was calculated using the following equation:

$$
O H \text { scavenging activity }(\%)=\left[1-\frac{\left(A_{1}-A_{2}\right)}{A_{0}}\right] \times 100
$$

Where $\mathrm{A}_{0}$ is the absorbance of the control (without SAP solution), $A_{1}$ is the absorbance of the SAP solution addition, $\mathrm{A}_{2}$ is the absorbance without $\mathrm{H}_{2} \mathrm{O}_{2}$.

\section{Determination of DPPH Radical Scavenging Activity}

The DPPH radical scavenging activity was measured according to the $\mathrm{Gu}$ et al. [16] with some modification. An aliquot of $2 \mathrm{~mL}$ the soybean peptides solution was mixed with $2 \mathrm{~mL}$ of $1 \mathrm{mM}$ freshly prepared DPPH (dissolved in $95 \%$ ethanol). The reaction mixture was allowed to react at room temperature for $30 \mathrm{~min}$, after which the absorbance at $517 \mathrm{~nm}$ was read. The blank substituted 2 $\mathrm{mL}$ ethanol for the soybean peptides solution. The radical scavenging activity of the tested reaction mixture was calculated by the following equation:

$$
D P P H \text { radical scavenging activity }(\%)=\frac{A_{1}-A_{2}}{A_{1}} \times 100
$$

Where $A_{1}$ is the absorbance of the blank at $517 \mathrm{~nm}$ and $\mathrm{A}_{2}$ is the absorbance of the SAP solution at $517 \mathrm{~nm}$. The DPPH test was executed in triplicate. 
E. Determination of Superoxide Anion Radical Scavenging Activity

The superoxide anion radical scavenging activity was measured following the method of Huang et al. [15] with some modifications. Briefly, $1 \mathrm{~mL}$ of SAP solution was mixed with $5 \mathrm{~mL}$ of Tris- $\mathrm{HCl}$ buffer $(0.1 \mathrm{M}, \mathrm{pH} 7.4)$. The mixture was incubated at $25^{\circ} \mathrm{C}$ for $20 \mathrm{~min}$, and then $50 \mu \mathrm{L}$ of pyrogallic acid $(3 \mathrm{mM})$ was added and incubated at
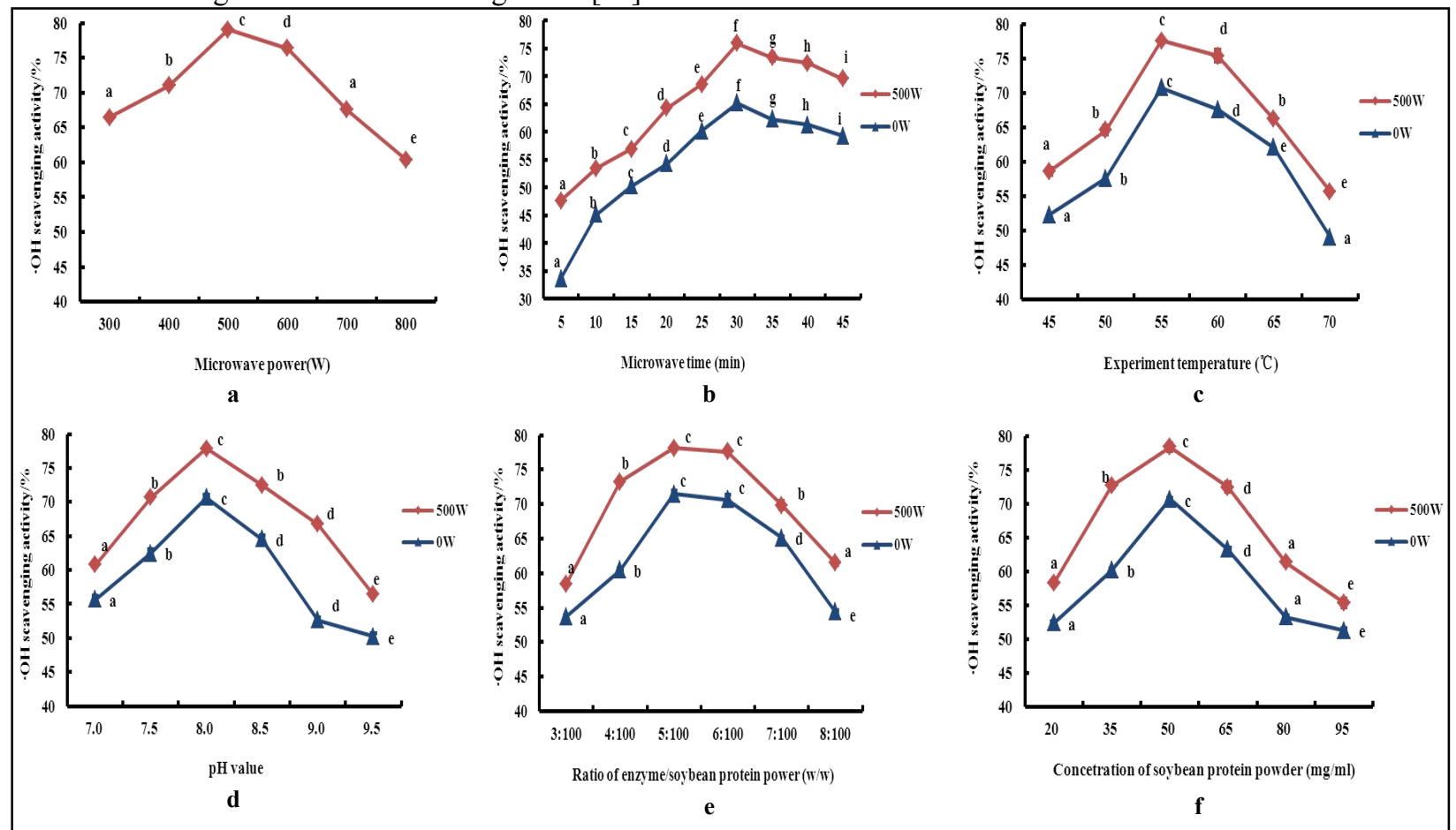

Figure 1. The effects of six independent variables on $\cdot \mathrm{OH}$ scavenging activity of soybean antioxidant peptides. a) microwave power, b) time, c) temperature, d) $\mathrm{pH}$ value, e) $[\mathrm{E} / \mathrm{S}], \mathrm{f})[\mathrm{S}]$. The same lower letter means that the variance of two samples is not significant $(\mathrm{P}>0.05)$.

same condition for $4 \mathrm{~min}$. The absorbance was read at 325 $\mathrm{nm}$ and all the measurements were carried out in triplicate.

Superoxide anion radical scavenging activity $(\%)=\left[1-\frac{\left(A_{t}-A_{2}\right)}{A_{0}}\right] \times 100$

Where $A_{1}$ is the absorbance with the presence of pyrogallic acid and SAP solution; $A_{0}$ is the presence of pyrogallic acid without soybean peptides solution; and $\mathrm{A}_{2}$ is the presence of SAP solution without pyrogallic acid.

\section{F. Determination of ABTS Radical Inhibition Activity}

ABTS radical inhibition activity of soybean peptides was determined using the method of Arnao et al. [17] with a slight modification. The ABTS $\bullet+$ was produced by reacting $7 \mathrm{mM}$ ABTS with $2.45 \mathrm{mM}$ potassium persulfate for $12-16$ hours in the dark at room temperature. Then, the ABTS $\bullet+$ solution was diluted in $0.2 \mathrm{M}$ phosphate buffer $(\mathrm{pH}$ 7.4) and prepared. For each assay, $100 \mu \mathrm{L}$ SAP solution were allowed to react with $4 \mathrm{~mL}$ of the ABTS•+ solution for $30 \mathrm{~s}$ in the dark. Then the absorbance was recorded at $734 \mathrm{~nm}$. The inhibition of ABTS•+ was calculated using following formula.

$$
\text { ABTS radical inhibition }(\%)=\left[1-\frac{\left(A_{0}-A_{2}\right)}{A_{1}}\right] \times 100
$$

Where $A_{1}$ is the absorbance of the blank at $734 \mathrm{~nm}, A_{2}$ is the absorbance of the contrast at $734 \mathrm{~nm}$ and $A_{0}$ is the absorbance of the soybean peptides solution addition at $734 \mathrm{~nm}$

\section{G. Statistical Analysis}

Values are expressed as the means \pm SD. Statistical comparisons between groups were performed using one- way analysis of variance (ANOVA). The significant difference was determined with $95 \%$ confidence intervals $(\mathrm{P}<0.05)$, the extremely significant difference was determined with $99 \%$ confidence intervals $(\mathrm{P}<0.01)$.

\section{RESULTS AND DISCUSSION}

\section{A. OFAT Experiments}

The effects of microwave power on the $\cdot \mathrm{OH}$ scavenging activity of SAP were shown in Fig .1a. The $\cdot \mathrm{OH}$ scavenging activity of SAP obtained from MAED was significantly affected by microwave power. Initially, the $\cdot \mathrm{OH}$ scavenging activity continued to rise with microwave power increasing. However, when the microwave power reached to $500 \mathrm{~W}$, the $\bullet \mathrm{OH}$ scavenging activity began to gradually decrease. The highest $\bullet \mathrm{OH}$ scavenging activity was $79.02 \%$, therefore, microwave power of $500 \mathrm{~W}$ was chosen as the best parameter of microwave power for the other experiments. $\mathrm{Li}$ et al. [18] found when the microwave power applied to the protein solution was from $300 \mathrm{~W}$ to $500 \mathrm{~W}$, the activities would gradually increase with power going up. If the microwave power was greater than $500 \mathrm{~W}$, an increase in microwave power resulted in decreased activity. The effects of microwave power on proteins may be due to the sharply increased temperature caused by the microwave power rising, which resulted in protein denaturation and sharply declined activity.

The effects of incubation time on the $\cdot \mathrm{OH}$ scavenging activity of SAP were shown in Fig .1b. As for the MAED$500 \mathrm{~W}$ sample, with the incubation time increasing from 5 
to $30 \mathrm{~min}$, the $\cdot \mathrm{OH}$ scavenging activity was significantly enhanced $(\mathrm{P}<0.05)$. The highest $\bullet \mathrm{OH}$ scavenging activity appeared to be $75.96 \% \pm 0.47 \%$ when the incubation time was $30 \mathrm{~min}$. On the other hand, the $\cdot \mathrm{OH}$ scavenging activity significantly decreased when the incubation time increased from 30 to $45 \mathrm{~min}$. In terms of the MAED-0W sample, when the incubation time was from 5 to $30 \mathrm{~min}$, the $\cdot \mathrm{OH}$ scavenging activity tended to increase with the time $(\mathrm{P}<0.05)$, and the highest $\cdot \mathrm{OH}$ scavenging activity was $65.23 \% \pm 0.49 \%$ when the incubation time was 30 min. But the $-\mathrm{OH}$ scavenging activity significantly decreased when the incubation time exceeded $30 \mathrm{~min}$. Therefore, incubation time of $30 \mathrm{~min}$ was selected as the best incubation time for the other experiments. At the same experimental conditions, the MAED-500W sample showed higher $\bullet \mathrm{OH}$ scavenging activity than MAED-0W sample significantly $(\mathrm{P}<0.05)$. Zhang et al. [14] investigated microwave-assisted approach for the rapid enzymatic digestion peanut protein, and they found the microwave energy can influence the protease structure and substrate protein structure. Besides, if the microwave treatment time is more than $15 \mathrm{~min}$, the enzyme will become inactive. On the contrary, the incubation time less than $15 \mathrm{~min}$ had little influence on the extraction. At the initial stage, the antioxidant peptides may be released resulting in increase in the antioxidant activity of the hydrolysis, while further process may lead to the hydrolysis of the antioxidant peptides into amino acids and thus destroy their antioxidant activity.

The effects of temperature on the $\cdot \mathrm{OH}$ scavenging activity of SAP was shown in Fig .1c. With the temperature increasing, the $\cdot \mathrm{OH}$ scavenging activity would rise in the beginning until the temperature reached a certain temperature, after which a downtrend was showed. With regards to the MAED-500W sample, when the microwave extraction temperature was increasing from 45 to $55^{\circ} \mathrm{C}$, the $\cdot \mathrm{OH}$ scavenging activity was significantly enhanced $(\mathrm{P}<0.05)$. However, if the temperature passed $55{ }^{\circ} \mathrm{C}$, an increase in temperature led to a significant decrease in the $\cdot \mathrm{OH}$ scavenging activity $(\mathrm{P}<0.05)$. And the highest value of $\bullet \mathrm{OH}$ scavenging activity was obtained at the temperature of $55{ }^{\circ} \mathrm{C}$. Regarding the MAED-0W sample, the $\cdot \mathrm{OH}$ scavenging activity underwent a significant increase from 45 to $55^{\circ} \mathrm{C}$ and a remarkable decrease from $55{ }^{\circ} \mathrm{C}$ to $70{ }^{\circ} \mathrm{C}(\mathrm{P}<0.05)$, and the highest value of $70.78 \% \pm 0.51 \%$ was achieved at $55^{\circ} \mathrm{C}$. Thus, $55{ }^{\circ} \mathrm{C}$ was chosen as the best parameter for the other experiments. At the same experimental conditions, the MAED-500W sample showed higher $\bullet \mathrm{OH}$ scavenging activity than MAED-0W sample $(\mathrm{P}<0.05)$. Recently, some researchers also found an obvious influence of the temperature factor on antioxidant activity of whey protein hydrolysates. The similar tendency to ours has been reported by Contreras et al [19].

The effects of the $\mathrm{pH}$ value on the $\cdot \mathrm{OH}$ scavenging activity of SAP was shown in Fig .1d. The changing trends of MAED-500W and MAED-0W sample with the variance of $\mathrm{pH}$ value were similar. With the $\mathrm{pH}$ value increasing from 7 to 8 , the $\cdot \mathrm{OH}$ scavenging activity of the MAED$500 \mathrm{~W}$ sample increased from $60.75 \% \pm 0.28 \%$ to 77.83 $\% \pm 0.24 \%$, and the $\cdot \mathrm{OH}$ scavenging activity of MAED$0 \mathrm{~W}$ sample also increased from $55.66 \% \pm 0.59 \%$ to
$70.65 \% \pm 0.38 \%$. However, the $\cdot \mathrm{OH}$ scavenging activity underwent a significant decrease when the $\mathrm{pH}$ value increased from 8 to $9(\mathrm{p}>0.05)$. Therefore, $\mathrm{pH} 8.0$ was chosen as the best parameter for the other experiments. Similar results have been reported by Guerard who investigated the antioxidant activities of shrimp processing discards and found that the application of $\mathrm{pH}$ value over 8.5 to shrimp processing discards could

Table 2. Box-Behnken design matrix and response values for $\cdot \mathrm{OH}$ scavenging activity

\begin{tabular}{|c|c|c|c|c|c|}
\hline No. & $\mathrm{X}_{1}$ & $\mathrm{X}_{2}$ & $\mathrm{X}_{3}$ & Actual activity (\%) & Predicted activity (\%) \\
\hline 1 & 0 & 0 & 0 & $81.25 \pm 0.52$ & 82.02 \\
\hline 2 & 0 & 0 & 0 & $82.65 \pm 0.35$ & 82.02 \\
\hline 3 & -1 & 0 & 1 & $73.68 \pm 0.33$ & 74.25 \\
\hline 4 & 0 & 1 & -1 & $77.34 \pm 0.93$ & 77.51 \\
\hline 5 & 1 & 0 & -1 & $75.35 \pm 0.58$ & 74.78 \\
\hline 6 & -1 & 0 & -1 & $72.35 \pm 0.62$ & 72.50 \\
\hline 7 & 1 & 1 & 0 & $75.68 \pm 0.44$ & 76.08 \\
\hline 8 & 0 & 1 & 1 & $79.89 \pm 0.76$ & 79.63 \\
\hline 9 & 0 & -1 & -1 & $76.86 \pm 0.64$ & 77.11 \\
\hline 10 & 1 & -1 & 0 & $75.32 \pm 0.77$ & 75.63 \\
\hline 11 & 0 & -1 & 1 & $78.23 \pm 0.51$ & 78.06 \\
\hline 12 & 0 & 0 & 0 & $81.56 \pm 0.38$ & 82.02 \\
\hline 13 & 1 & 0 & 1 & $76.25 \pm 0.32$ & 76.10 \\
\hline 14 & -1 & 1 & 0 & $74.86 \pm 0.14$ & 74.55 \\
\hline 15 & -1 & -1 & 0 & $73.43 \pm 0.47$ & 73.03 \\
\hline 16 & 0 & 0 & 0 & $82.64 \pm 0.35$ & 82.02 \\
\hline 17 & 0 & 0 & 0 & $82.01 \pm 0.58$ & 82.02 \\
\hline
\end{tabular}

gradually increase the antioxidant activities, but the further increase in $\mathrm{pH}$ value seemed to decrease the activity if the $\mathrm{pH}$ value was over 9.1 [20].

The effects of ratio of enzyme to soybean protein powder on the $-\mathrm{OH}$ scavenging activity of SAP was shown in Fig. 1e. When the ratio was increased from 3:100 to $5: 100$, the - OH scavenging activity of the MAED$500 \mathrm{~W}$ sample was increased significantly as well as the MAED-0W sample $(\mathrm{P}<0.05)$. Then the highest values of $78.12 \% \pm 0.43 \%$ and $71.48 \% \pm 0.59 \%$ at the ratio of 5:100 were obtained. When the ratio was increased from 5:100 to $6: 100$, there are no obvious changes between the two experiment points $(\mathrm{P}>0.05)$. The $\bullet \mathrm{OH}$ scavenging activity significantly decreased $(\mathrm{P}<0.05)$ when the ratio increased from $6: 100$ to $8: 100$. Therefore, 5:100 was chosen as the best ratio parameter for the other experiments. You et al tested the antioxidant activities of Papain to hydrolysate of fish gelatin, and the results exhibited the similar tendency [21].

The effects of concentration of soybean protein powder on the $\cdot \mathrm{OH}$ scavenging activity of SAP was shown in Fig .1f. For both MAED-500W sample and MAED-0W sample, the $\cdot \mathrm{OH}$ scavenging activity changed significantly $(\mathrm{P}<0.05)$ when the concentration varied. When the concentration was controlled at $50 \mathrm{mg} / \mathrm{mL}$, the highest value was obtained. The highest $\bullet \mathrm{OH}$ scavenging activity of MAED-500W sample reached to $78.34 \% \pm$ $0.46 \%$, while $71.64 \% \pm 0.31 \%$ for MAED-0W sample. When the concentration was increased from $50 \mathrm{mg} / \mathrm{mL}$ to $95 \mathrm{mg} / \mathrm{mL}$, the $\cdot \mathrm{OH}$ scavenging activity decreased significantly $(\mathrm{P}<0.05)$. Therefore, $50 \mathrm{mg} / \mathrm{mL}$ was chosen as the best parameter for the other experiments. 


\section{B. RSM experiments}

RSM was used to optimize the MAED conditions for processing SAP with the highest $-\mathrm{OH}$ scavenging activity. The influences of microwave time, microwave temperature and $\mathrm{pH}$ value on the $-\mathrm{OH}$ scavenging activity were shown in table 2. A response surface quadratic model was drawn. The statistical analyses of the linearity, the quadratic and the interaction of the three variables $\left(\mathrm{X}_{1}, \mathrm{X}_{2}\right.$

Table 3. Regression coefficients estimate and significance test for the quadratic polynomial model

\begin{tabular}{|c|c|c|c|c|c|c|}
\hline $\begin{array}{c}\text { Model } \\
\text { term }\end{array}$ & $\begin{array}{c}\text { Coefficient } \\
\text { estimate }\end{array}$ & \multicolumn{2}{|c|}{$\begin{array}{c}\text { Standard error } \\
\text { Sum of square }\end{array}$} & $\begin{array}{c}\text { Mean } \\
\text { square }\end{array}$ & F-value & $\begin{array}{c}\text { signifi } \\
\text {-ance }\end{array}$ \\
\hline Model & 186.23 & 9.00 & 20.69 & 48.59 & $<0.0001$ & $* *$ \\
\hline $\mathrm{X}_{1}$ & 8.57 & 1.00 & 8.57 & 20.13 & 0.0028 & $*$ \\
\hline $\mathrm{X}_{2}$ & 1.93 & 1.00 & 1.93 & 4.53 & 0.0707 & \\
\hline $\mathrm{X}_{3}$ & 4.73 & 1.00 & 4.73 & 11.10 & 0.0126 & $*$ \\
\hline $\mathrm{X}_{1} \times \mathrm{X}_{2}$ & 0.29 & 1.00 & 0.29 & 0.67 & 0.4393 & \\
\hline $\mathrm{X}_{1} \times \mathrm{X}_{3}$ & 0.046 & 1.00 & 0.046 & 0.11 & 0.7514 & \\
\hline $\mathrm{X}_{2} \times \mathrm{X}_{3}$ & 0.35 & 1.00 & 0.35 & 0.82 & 0.3960 & $* *$ \\
\hline $\mathrm{X}_{1}{ }^{2}$ & 124.42 & 1.00 & 124.42 & 292.20 & $<0.0001$ & $* * 1$ \\
\hline $\mathrm{X}_{2}{ }^{2}$ & 13.09 & 1.00 & 13.09 & 30.75 & 0.0009 & $* *$ \\
\hline $\mathrm{X}_{3}{ }^{2}$ & 19.98 & 1.00 & 19.98 & 46.93 & 0.0002 & $* *$ \\
\hline Residual & 2.98 & 7.00 & 0.43 & & & \\
\hline Lack of Fit & 1.39 & 3.00 & 0.46 & 4.46 & 0.0914 & \\
\hline Pure Error & 1.59 & 4.00 & 0.40 & & & \\
\hline Cor Total & 189.21 & 16.00 & & & & \\
\hline
\end{tabular}

Table 4. Antioxidant activities of SAP used the DPPH, superoxide anion, ABTS radical scavenging assy.

\begin{tabular}{|c|c|c|c|}
\hline $\begin{array}{c}\text { Soybean } \\
\text { peptides }\end{array}$ & $\begin{array}{c}\mathrm{IC}_{50} / \mathrm{DPPH} \\
\text { radical } \\
(\mathrm{mg} / \mathrm{mL})\end{array}$ & $\begin{array}{c}\mathrm{IC}_{50} / \text { Superoxide } \\
\text { anion radical } \\
(\mathrm{mg} / \mathrm{mL})\end{array}$ & $\begin{array}{c}\mathrm{IC}_{50} / \mathrm{ABTS} \\
\text { radical }(\mathrm{mg} / \mathrm{mL})\end{array}$ \\
\hline MAED-500W & $0.652 \pm 0.007$ & $1.250 \pm 0.046$ & $0.674 \pm 0.008$ \\
\hline MAED-0W & $0.839 \pm 0.006$ & $1.810 \pm 0.061$ & $0.967 \pm 0.049$ \\
\hline
\end{tabular}

and $\left.\mathrm{X}_{3}\right)$ on the response values $(\mathrm{Y})$ were presented in the table 3. The P-value for the model was less than 0.0001 , which indicated that the model was significant and could be used to monitor the optimization. Among the three independent variables, microwave time exerted an extremely significant effect on the $\cdot \mathrm{OH}$ scavenging activity within a $99 \%$ confidence interval $(\mathrm{P}=0.0028<$ 0.01 for $\mathrm{X}_{1}$ ); $\mathrm{pH}$ value exerted a significant effect on the $\cdot \mathrm{OH}$ scavenging activity within a $95 \%$ confidence interval $\left(\mathrm{P}=0.0126<0.05\right.$ for $\left.\mathrm{X}_{3}\right)$; In terms of the quadratic $\mathrm{X}_{1} \times \mathrm{X}_{1}(\mathrm{P}<0.01), \mathrm{X}_{2} \times \mathrm{X}_{2}(\mathrm{P}<0.01)$ and $\mathrm{X}_{3} \times \mathrm{X}_{3}(\mathrm{P}<$ $0.01)$ were all within a $99 \%$ confidence interval. Therefore the changes of the response value were very complex, and the effect of each experimental factor on the $-\mathrm{OH}$ scavenging activity did not show a simple linear relationship but a second-order relationship. The statistical analysis for the model (table 3 ) showed the "lack of fit" was not significant $(\mathrm{P}=0.0914>0.05)$. The low R-Squared value indicated a poor relevance of the dependent variables in the model. When the R-Squared approaches unity, the model fitted well with the experimental data. As shown in table 3, a good agreement between the experimental results with a coefficient (R-Squared) of 0.9842 was found. Therefore, this model proved to be powerful for navigating the design space.

The 3-D response surface and 2-D contour plots described the regression function realistically, showing the type of interactions between the variables and the relationship between responses and experiment levels of each variable. A circular contour plot indicated that the interactions between the corresponding variables were negligible, while elliptical contour plot indicated otherwise [16]. The response and contour were obtained using Expert
7.0 software. Effects of microwave time, microwave temperature and $\mathrm{pH}$ value on $\cdot \mathrm{OH}$ scavenging activity were illustrated in Fig .2. The effects of microwave time and microwave temperature were illustrated in Fig .2a and $2 \mathrm{~b}$, where the $\mathrm{pH}$ value remained constant at 8.0. The Fig $.2 \mathrm{a}$ and $2 \mathrm{~b}$ indicated that the $\cdot \mathrm{OH}$ scavenging activity increased at first and then decreased with the increase of microwave time $\left(\mathrm{X}_{1}\right)$. In terms of microwave temperature $\left(\mathrm{X}_{2}\right)$, both low $\left(45{ }^{\circ} \mathrm{C}\right)$ temperature and high $\left(60{ }^{\circ} \mathrm{C}\right)$ temperature in this model led to a low $\cdot \mathrm{OH}$ scavenging activity. The maximum $\bullet \mathrm{OH}$ scavenging activity was observed at around $56{ }^{\circ} \mathrm{C}$. This result also showed that the $\cdot \mathrm{OH}$ scavenging activity had a curvilinear relationship with the microwave temperature and the quadratic term was significant. Effects of microwave time $\left(\mathrm{X}_{1}\right)$ and $\mathrm{pH}$ value $\left(\mathrm{X}_{3}\right)$ were shown in Fig $.2 \mathrm{c}$ and $2 \mathrm{~d}$, where the microwave temperature was constant at $55^{\circ} \mathrm{C}$. A maximum - $\mathrm{OH}$ scavenging activity was observed at around $29-31 \mathrm{~min}$ and about $\mathrm{pH} 7.75$ to 8.25. Fig . $2 \mathrm{c}$ and $2 \mathrm{~d}$ showed that $\cdot \mathrm{OH}$ scavenging activity increased when the microwave time increased from approximately 25 to $31 \mathrm{~min}$. However, further increased microwave time from 31 to 35 min caused a decrease in $\mathrm{OH}$ scavenging activity. When the $\mathrm{pH}$ value increased from approximately 7.5 to 8.2 caused an increase in $\cdot \mathrm{OH}$ scavenging activity; Further increased $\mathrm{pH}$ value from 8.2 to 9.0 caused a decrease. Fig .2e and $2 \mathrm{f}$ showed that the $\mathrm{pH}$ value $\left(\mathrm{X}_{3}\right)$ and microwave temperature $\left(\mathrm{X}_{2}\right)$ demonstrated quadratic effects on the $\cdot \mathrm{OH}$ scavenging activity when the microwave time was fixed at $30 \mathrm{~min}$. The results confirmed that the predicted maximum $\cdot \mathrm{OH}$ scavenging activity (Y) of $82.17 \%$ was obtained with the following conditions: microwave time of $30.45 \mathrm{~min}$, microwave temperature of $56^{\circ} \mathrm{C}$, pH value of 8.09 , [E/S] of $5: 100$, [S] of $50 \mathrm{mg} / \mathrm{mL}$, microwave power $500 \mathrm{~W}$. While the actual maximum $\cdot \mathrm{OH}$ scavenging activity $(\mathrm{Y})$ of $82.55 \% \pm$ 0.41 was obtained with the following conditions: microwave time of $31 \mathrm{~min}$, microwave temperature of 56 ${ }^{\circ} \mathrm{C}, \mathrm{pH}$ of value $8.09,[\mathrm{E} / \mathrm{S}]$ of $5: 100,[\mathrm{~S}]$ of $50 \mathrm{mg} / \mathrm{mL}$, microwave power of $500 \mathrm{~W}$. The error between the practical value and actual value was less than $1 \%$, which proved the model was valid. The $\bullet \mathrm{OH}$ scavenging activity of the MAED-0W sample was $70.62 \% \pm 0.065$.

The SAP processed by MAED under the optimal conditions was MAED-500W sample. The MAED-0W sample was obtained under the same conditions except the microwave power (microwave power was $0 \mathrm{~W}$ ). We evaluated the antioxidant activity of MAED-500W and MAED-0W sample using the three methods of DPPH, superoxide anion, ABTS radical scavenging activity, respectively. The $\mathrm{IC}_{50}$ was calculated in table 4 . The lower $\mathrm{IC}_{50}$ value implied the greater free radical scavenging activity. The $\mathrm{IC}_{50}$ values of $\mathrm{DPPH}$ radical scavenging activity were $0.652 \pm 0.007,0.839 \pm 0.006$ for MAED$500 \mathrm{~W}$ sample and MAED-0W sample, respectively. As for the superoxide anion and ABTS radical scavenging activity, the MAED-0W sample was stronger, which was similar to the results of DPPH radical scavenging activity. The $\mathrm{IC}_{50}$ values of superoxide anion were $1.250 \pm 0.046$ and $1.810 \pm 0.061$ for MAED-500W and MAED-0W sample, respectively. The $\mathrm{IC}_{50}$ values of ABTS were 0.674 \pm 0.008 and $0.967 \pm 0.049$ for MAED-500W and MAED- 
0W sample, respectively. These results revealed that MAED-500W sample had significant $(\mathrm{P}<0.05)$ higher scavenging activity than MAED-0W sample. Ma et al. [22] found that the microwave extracted oil from Schisandra chinensis Baill showed a stronger DPPH radical scavenging activity than the steam-distillation extracted one. Li et al. [23] reported microwave-assisted organic acid extraction of lignin from bamboo presented a higher radical scavenging activity than butylated hydroxytoluene.

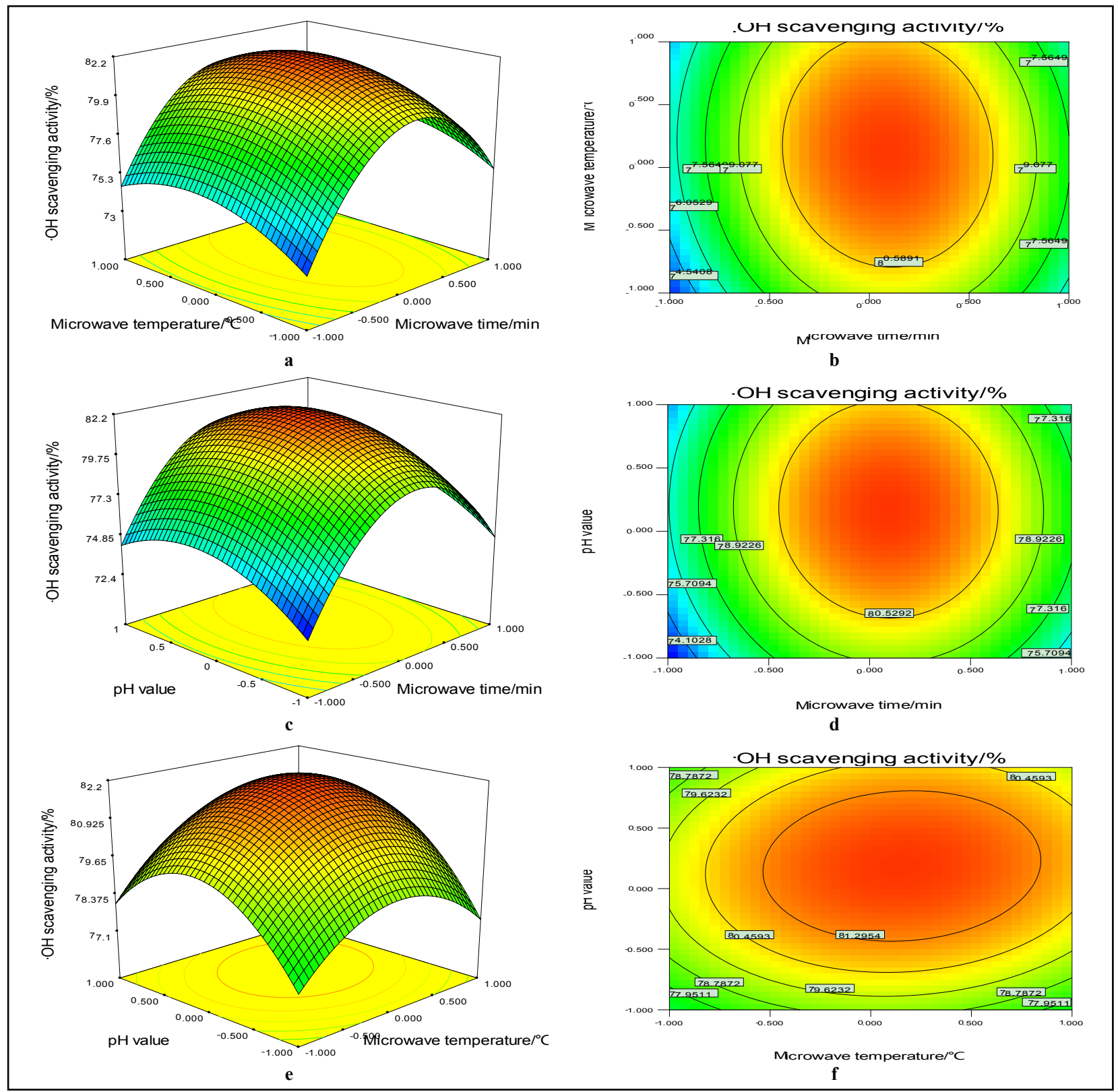

Figure 2. Response surface plots and contour plots of $\cdot \mathrm{OH}$ scavenging activity of the soybean antioxidant peptides. The $\cdot \mathrm{OH}$ scavenging activity is shown as a function of the interactions between microwave time and microwave temperature $(\mathrm{a}, \mathrm{b})$, microwave time and $\mathrm{pH}$ value $(\mathrm{c}, \mathrm{d})$, microwave temperature and $\mathrm{pH}$ value $(\mathrm{e}, \mathrm{f})$.

This may explain the fact that microwave-assisted extraction can improve the antioxidant activity. However, more work needs to be done to elucidate the effects of MAED on the structure and in vivo antioxidant activity of SAP in the future.

\section{CONCLUSIONS}

In conclusion, the optimal MAED processing parameters (microwave time of $30.45 \mathrm{~min}$, microwave temperature of $56^{\circ} \mathrm{C}$, pH value of 8.09 , [E/S] of $5: 100,[\mathrm{~S}]$ of $50 \mathrm{mg} / \mathrm{mL}$, microwave power of $500 \mathrm{~W}$ ) were obtained via the RSM coupled with OFAT tests. Under the optimized conditions, the MAED-500W sample of SAP showed an increase in $\cdot \mathrm{OH}$ scavenging activity of 11.93 $\%$ compared with the MAED-0W sample. On the other hand, the MAED-500W sample demonstrated stronger antioxidant activities in DPPH radical, superoxide anion radical and ABTS radical scavenging, with $\mathrm{IC}_{50}$ value of $0.652 \pm 0.007,1.250 \pm 0.046,0.674 \pm 0.008 \mathrm{mg} / \mathrm{mL}$ respectively, than the MAED-0W sample $(\mathrm{P}<0.05)$. It can be concluded that the MAED technology has potentials to improve the antioxidant activity. Much more work should be done in the future to clarify the relation between the 
improved antioxidant activity and the changed functional groups.

\section{ACKNOWLEDGEMENTS}

This work was supported by the Grant 31271907 and 31471597 of the National Natural Science Foundation of China, the Specialized Research Fund for the Doctoral Program of Higher Education (No. 20130061110088), and the Project of National Key Technology Research and Development Program (NO. 2012BAD33B03).

\section{REFERENCES}

[1] S. LIN, Y. GUO, Q. I. YOU, Y. YIN, J. LIU and P. G. LUO, "Effects of high-intensity pulsed electric field on antioxidant attributes of hydrolysates derived from egg white protein," Journal of Food Biochemistry 2013, vol. 37, pp. 45-52.

[2] S. LIN, Y. JIN, M. LIU, Y. YANG, M. ZHANG, Y. GUO, G. JONES, J. LIU and Y. YIN, "Research on the preparation of antioxidant peptides derived from egg white with assisting of highintensity pulsed electric field," Food Chem 2013, vol. 139, pp. 3006.

[3] S.-H. BAE and H.-J. SUH, "Antioxidant activities of five different mulberry cultivars in korea," LWT - Food Science and Technology 2007, vol. 40, pp. $955-962$.

[4] B. N. AMES, M. K. SHIGENAGA and T. M. HAGEN, "Oxidants, antioxidants, and the degenerative diseases of aging," Proc Natl Acad Sci U S A 1993, vol. 90, pp. 7915-7922.

[5] S. C. KO, D. KIM and Y. J. JEON, "Protective effect of a novel antioxidative peptide purified from a marine chlorella ellipsoidea protein against free radical-induced oxidative stress," Food Chem Toxicol 2012, vol. 50, pp. 2294-302.

[6] H.-M. CHEN, K. MURAMOTO, F. YAMAUCHI, K. FUJIMOTO and K. NOKIHARA:, "Antioxidative properties of histidinecontaining peptides designed from peptide fragments found in the digests of a soybean protein," J. Agric. Food Chem. 1998, vol. 46, pp. $49-53$.

[7] S. J. BISHOV and A. S. HENICK, "Antioxidant effect of protein hydrolysates in a freeze-dried model system," J Food Sci 1972, vol. 37, pp. 873-875.

[8] E. A. PENA-RAMOS and Y. L. XIONG, "Antioxidant activity of soy protein hydrolysates in a liposomal system," J Food Sci 2002, vol. 67 , pp. 2952-2956.

[9] M. OVISSIPOUR, R. SAFARI, A. MOTAMEDZADEGAN and B. SHABANPOUR, "Chemical and biochemical hydrolysis of persian sturgeon (acipenser persicus) visceral protein," Food and Bioprocess Technology 2009, vol. 5, pp. 460-465.

[10] Q. LIU, B. KONG, Y. L. XIONG and X. XIA, "Antioxidant activity and functional properties of porcine plasma protein hydrolysate as influenced by the degree of hydrolysis," Food Chemistry 2010, vol. 118, pp. 403-410.
[11] H. ENGELHARDTL, M. KRAMERL and H. WALDHOFF, "Enhancement of protein detection by microwave-induced hydrolysis and opa derivatization," Chromatographia 1990, vol. 30, pp. 523-526.

[12] H. F. JUAN, S. C. CHANG, H. C. HUANG and S. T. CHEN, "A new application of microwave technology to proteomics," Proteomics 2005, vol. 5, pp. 840-2.

[13] B. N. PRAMANIK, U. A. MIRZA, Y. H. ING, Y. H. LIU, P. L BARTNER, P. C. WEBER and A. K. BOSE, "Microwave-enhanced enzyme reaction for protein mapping by mass spectrometry: A new approach to protein digestion in minutes," Protein Sci 2002, vol. 11, pp. 2676-87.

[14] H. ZHANG, L. YU, Q. YANG, J. SUN, J. BI, S. LIU, C. ZHANG and L. TANG, "Optimization of a microwave-coupled enzymatic digestion process to prepare peanut peptides," Molecules 2012, vol. 17 , pp. 5661-74

[15] X. HUANG, Z. TU, Y. JIANG, H. XIAO, Q. ZHANG and H WANG, "Dynamic high pressure microfluidization-assisted extraction and antioxidant activities of lentinan," Int J Bio Macromol 2012, vol. 51, pp. 926-32.

[16] L. GU, M. ZHAO, W. LI, L. YOU, J. WANG, H. WANG and J. REN, "Chemical and cellular antioxidant activity of two novel peptides designed based on glutathione structure," Food Chem Toxicol 2012, vol. 50, pp. 4085-91.

[17] M. B. ARNAO, A. CANO and M. ACOSTA, "The hydrophilic and lipophilic contribution to total antioxidant activity. Food chem. 2001, 73, 239-244.," Food Chem 2001, vol., pp. 239-244.

[18] J.-F. LI, F. WEI, X.-Y. DONG, L.-L. GUO, G.-Y. YUAN, F.-H. HUANG, M.-L. JIANG, Y.-D. ZHAO, G.-M. LI and H. CHEN, "Microwave-assisted approach for the rapid enzymatic digestion of rapeseed meal," Food Science and Biotechnology 2010, vol. 19, pp. 463-469.

[19] M. d. M. CONTRERAS, B. HERN NDEZ-LEDESMA, L. AMIGO, P. J. MART N-ÁLVAREZ and I. RECIO, "Production of antioxidant hydrolyzates from a whey protein concentrate with thermolysin: Optimization by response surface methodology," LWT - Food Science and Technology 2011, vol. 44, pp. 9-15.

[20] F. GUERARD, M. T. SUMAYA-MARTINEZ, D. LAROQUE, A CHABEAUD and L. DUFOSS "Optimization of free radical scavenging activity by response surface methodology in the hydrolysis of shrimp processing discards," Process Biochemistry 2007, vol. 42, pp. 1486-1491.

[21] L. J. YOU, J. M. REGENSTEIN and R. H. LIU, "Optimization of hydrolysis conditions for the production of antioxidant peptides from fish gelatin using response surface methodology," J Food Sci 2010, vol. 75, pp. C582-C587.

[22] C. H. MA, L. YANG, Y. G. ZU and T. T. LIU, "Optimization of conditions of solvent-free microwave extraction and study on antioxidant capacity of essential oil from schisandra chinensis (turcz.) baill," Food Chem 2012, vol. 134, pp. 2532-9.

[23] M. F. LI, S. N. SUN, F. XU and R. C. SUN, "Microwave-assisted organic acid extraction of lignin from bamboo: Structure and antioxidant activity investigation," Food Chem 2012, vol. 134, pp. $1392-8$. 